\author{
British Journal of Education, Society \& \\ Behavioural Science \\ 6(3): 210-217, 2015, Article no.BJESBS.2015.057 \\ ISSN: 2278-0998 \\ SCIENCEDOMAIN international \\ www.sciencedomain.org
}

\title{
The Relative Effectiveness of Collaborative Learning Approach on Secondary School Students' Understanding of the Concept of Electromagnetic Induction
}

\author{
T. Adolphus ${ }^{1^{*}}$, F. A. Onwioduokit ${ }^{2}$ and J. W. Dike ${ }^{2}$ \\ ${ }^{1}$ Department of Science and Technical Education, Rivers State University of science and Technical \\ Education, Nkpolu-Oroworukwo, Port Harcourt, Nigeria. \\ ${ }^{2}$ Department of Curriculum Studies and Educational Technology, University of Port Harcourt, Nigeria.
}

Authors' contributions

This work was carried out in collaboration between all authors. Author TA designed the study, performed the statistical analysis, wrote the protocol, and wrote the first draft of the manuscript. Authors FAO and JWD made several reviews of the original work, directed the methodology of the study and suggested several corrections. Author TA managed the literature searches and general corrections. All authors read and approved the final manuscript.

Article Information

DOI:10.9734/BJESBS/2015/9427 Editor(s):

(1) Rajendra Badgaiyan, Faculty of Psychiatry and Neuromodulation Scholar, University of Minnesota, Minneapolis, MN, USA

Reviewers:

(1) Jenaro Guisasola, Applied Physics. University of the Basque Country (UPV/EHU). Spain.

(2) Anonymous, Indonesia. Complete Peer review History: http://www.sciencedomain.org/review-history.php?iid=820\&id=21\&aid=7781

Original research article

Received $10^{\text {th }}$ February 2014

Accepted $9^{\text {th }}$ April 2014

Published $14^{\text {th }}$ January 2015

\begin{abstract}
This study compared the relative effectiveness of Collaborative and Demonstration Teaching Approaches on students' conceptual understanding of electromagnetic induction in secondary schools in Nigeria. Two research questions and one hypothesis were formulated to guide the research. The quasi experimental design was adopted for this study. The population of the study is made up of the 323 Senior Secondary III physics students in all six public co-educational Senior Secondary schools in Port Harcourt local Government Area. A sample of 180 students, comprising 120 males and 60 females, were selected for the study. Simple Means, Standard Deviation and Variance were used to answer research questions while t-test was utilized for the testing of the hypothesis. The results show that students taught with Collaborative Learning Approach understood
\end{abstract}

*Corresponding author: Email: telimabel@yahoo.com; 
better than those taught with Demonstration Approach. Based on the effectiveness of the Collaborative learning approach, it is recommended that teachers be acquainted with the techniques and use of collaborative and other constructivists teaching approaches in science classrooms.

Keywords: Collaborative learning; electromagnetic induction; co-educational.

\section{INTRODUCTION}

Electromagnetic induction is a phenomenon whereby an electro motive force (e.m.f) is produced or induced in a conductor due to the relative motion of an electric conductor and a magnetic field. According to [1], 'Electromagnetic induction is the generation of an electromotive force when the magnetic flux linkage through a coil changes or a conductor cuts across magnetic field lines' (p.262). Illustrating the concept of electromagnetic induction, [2], explained that 'when a straight conductor is perpendicular to a magnetic field, there is a relative motion between the conductor and the magnetic field. Likewise when a magnetic field is moved past a stationary conductor, there is also relative motion. I either case, this relative motion results in an induced voltage across the conductor. This principle is known as Electromagnetic induction'. Electromagnetic induction is the production of voltage across a conductor moving through a magnetic field. It underlies the operation of generators, transformers, inductor motors, all electric motors and solenoids. Michael Faraday is generally credited with the discovery of the electromagnetic induction phenomenon in 1831. Faraday studied the magnetic field around a conductor carrying a Direct Current (DC) and established the basis for the electromagnetic field concept in physics. He discovered electromagnetic induction and his inventions of electromagnetic rotary devices formed the foundation of electric motor technology, and it was largely due to his efforts that electricity became viable for use in technology [3]. Joseph Henry discovered the electromagnetic phenomenon of self-inductance and mutual inductance independently of Michael Faraday, but did not publish his findings until Faraday published his results [3]. This is why the discovery of electromagnetic induction is credited to Faraday. Electromagnetic induction is taught in senior secondary school (SSS) three physics in the current 6-3-3-4 system of education in Nigeria.

In a study conducted by [4] as cited by [5], the physics students performed worst in conservation principles and fields (where electromagnetic induction is taught). The study also reported that teachers did worst in the same concept (fields). Studies have shown that the major cause of difficulty in the formation of physics concepts at the secondary school level has been the improper teaching of the subject $[5,6,7]$. In Kenya, the experience is the same. The strengthening of Mathematics and Science in Secondary Education (SMASSE) project in Kenya reported that $64 \%$ of teachers interviewed during the baseline survey indicated that electromagnetic induction was a difficult topic [8]. In attempting to explain students' difficulties in understanding the concept of electromagnetic induction, [9] opined that students make meaning of current learning tasks by a combination of formal and informal everyday day experiences. They argued further that "while everyday experience makes an impact on some alternative conceptions, some areas of physics have no obvious parallels in everyday experience" (p.2693). They considered electromagnetic induction as one of the concepts in physics where everyday prior experience does not make a reasonable impact. [10] attributed the challenge or difficulty in students' understanding of electromagnetic induction to the use of ambiguous terminologies in explaining the concept. They mentioned the use of the terms 'area change' and 'change in orientation' that are used in many textbooks as ambiguous. They also argued that the unclear relation between Faraday's law and Maxwell's equation for the electric field circulation' (p. 337) as a challenge in the teaching of electromagnetic induction.

It is evident from the foregoing that science educators and indeed all stakeholders in the teaching and learning of science are in search of better teaching and learning strategies that will enable physics students gain proper understanding and application of physics concepts and principles. The traditional teachercentered instruction where the teacher is seen as a 'knowledge dispenser' dishing out facts to passive learners with its accompanying drill and practice is no longer desired for effective learning. In the view of [11], teacher would need to 'develop a new, well-articulated rationale for 
instructional decisions and cannot depend on their previous teaching or learning experiences for much help in shaping their choice of methods' (p.169). The essence here is to produce learners who can think critically and make sense out of their classroom experiences. The interest of the researcher is therefore to identify more effective teaching approach that will enhance the teaching and learning of electromagnetic induction in secondary school physics.

Several science educators have outlined methods of teaching science $[7,12,13,14]$. Some of the methods mentioned include lecture, question-answer problem solving, play-way, discovery, field trip, demonstration, project method; Computer Assisted Instruction (CAI) and collaborative approach. The choice of any or some of these methods in science teaching depends on the age, content availability of resources, previous knowledge and the teacher's versatility $[12,13]$. The researcher shall compare the relative effectiveness of collaborative learning strategy and demonstration methods on student understanding and application of the concept of electromagnetic induction.

Collaborative learning is a situation in which two or more people learn or attempt to learn something [15]. Collaborative learning is a constructivist strategy. More specifically, collaborative learning is based on the model that knowledge can be created within a population where members actively interact by sharing experiences and take on asymmetry roles [16]. Collaborative learning refers to methodologies and environments in which learners engage in a common task where each individual depends on and is accountable to each other. Very often, collaborative learning is used as an umbrella term for a variety of approaches in education that involve joint intellectual efforts by students and teachers [17].

Physics, as one of the natural sciences has been recognized as the bedrock for technological accomplishments and development. It is against this background that science educators are increasingly seeking ways of improving the quality of teaching and learning physics in our secondary schools. One of the general objectives of the physics curriculum as stated in the curriculum document is to: "Provide basic literacy in physics for functional living in the society" [18]. It is therefore very important to bear these objectives in mind, so that what we teach, how we present it and to whom, can only be decided when we know what we are trying to achieve. In line with these objectives, we recognize the role of physics in nation building. The teaching of physics should show how facts are established by experiment and observation, how generalizations are built upon this knowledge and concepts developed. When this is achieved, our secondary school leavers should be able to adapt to the rapid and drastic changes in technology and social culture.

\subsection{Statement of the Problem}

Electromagnetism is one of the perceived difficult concepts by both students and teachers in senior secondary physics [4,8]. [6] highlighted the factors militating against the teaching and learning of science to include the teaching approach. There is considerable evidence in the literature to show that traditional physics instruction predominantly based on lectures and manipulation of formulae, to teach concepts is ineffective [12,19,20,21]. In typical classroom setting, if students are involved in only passive learning, it would lead to limited knowledge retention, let alone engaging them in thinking or promoting functional understanding. Research works have shown that involving students directly and actively in the learning process promotes meaningful learning $[22,23,24]$.

Unfortunately, the current trend in the teaching and learning of physics, where materials for teaching are not available in public schools [25], has forced most teachers to use the traditional lecture method in teaching physics $[7,13]$. This has made it difficult to realize the importance of physics in our national development. From the foregoing therefore, the difficulty students have in understanding the concept of electromagnetic induction and the quest for better ways of effectively teaching the concept was the drive for this study. This research work therefore explores constructivists teaching strategy, particularly, collaborative learning strategy in enhancing students' conceptual understanding of electromagnetic induction. For teaching to be effective in promoting learning and enhancing students' understanding of concepts, it must involve interaction between teachers and students. The interaction should be such that it encourages students to get involved in working and forming meaning of experiences themselves. The problem of this study therefore is to find out whether collaborative learning approach compared to demonstration approach could enhance physics students' conceptual understanding and application of electromagnetic 
induction in secondary schools in Port Harcourt Local Government Area of Rivers State.

\subsection{Purpose of the Study}

The purpose of the study is to compare the relative effectiveness of collaborative and demonstration approaches on the conceptual understanding and application of electromagnetic induction in secondary school physics in Port Harcourt Local Government Area. Specifically, the study intends to:

1. Find out the effect of collaborative learning strategy on students' understanding of the concept of electromagnetic induction

2. Determine the effects of collaborative learning strategy on students' ability to apply the concepts of electromagnetic induction.

\subsection{Research Questions}

To guide the research, the following research questions are developed:

1. What are the effects of collaborative learning approach on students' understanding of the concept of electromagnetic induction?

2. Compare the effects of Collaborative and Demonstration Approaches on students' understanding of electromagnetic induction.

\subsection{Hypothesis}

There is no significant difference between the mean performances of students taught using Collaborative Learning Approach and those taught using Demonstration Approach with respect to understanding of the concept of electromagnetic induction.

\section{METHODOLOGY}

The research design adopted for this study was quasi-experimental. Precisely, the Nonrandomized, Pretest-posttest, control group design was used with teaching approaches as independent variable, students' understanding as dependent variable. Senior Secondary 3 physics students in all six (6) public co-educational Senior Secondary schools in Port Harcourt Local Government Area were used for the study. The Senior Secondary 3 class was purposively selected for this study because electromagnetic induction is taught in that class as in the senior secondary physics curriculum in Nigeria. In
Nigeria, the mean age of students in this class is about 17 years. Using the Taro Yamane's [26] formulae for sample size, a minimum sample size drawn was 179 students. By simple random sampling, a sample of one hundred and eighty (180) students, comprising 120 males and 60 females were selected for the study. The selected students were randomly sampled into the "experimental" and "control" groups. The normal school period for physics was used for the study. Three (3) periods per week of 40 minutes/period for two (2) weeks was used for the study. The constructivist Collaborative Learning Approach was used for the experimental group while the Demonstration approach was used for the control group. The collaborative teaching approach where the teacher activities is characterized by facilitating learning, guiding instruction and answering questions to clear doubts was adopted for the experimental group. In this group, Students with all resources available discuss, question one another, carry out demonstrations, experimenting, constructing knowledge with explanation among themselves to formulate solution to given tasks. For the Demonstration group, Teacher and students demonstrations were carried out with the teacher clarifying concepts and giving required guidance for the coverage of the content. The teacher used a peer reviewed lesson plans for both strategies.

The research instrument developed and used for this study was the 'Test on Electromagnetic Induction' (TOEI). The instrument was composed of 50 questions covering the content area and testing the various levels of understanding. The TOEI is made up of standardized objective questions adapted from past question papers of Senior Secondary School Certificate Examinations (SSCE), National Examination Council (NECO) and Joint Admission and Matriculation Board (JAMB) Examinations in Nigeria. The TOEI was used for both pre-test and post-test. The TOEI was designed to measure students' understanding of electromagnetic induction. The reliability coefficient of the instrument was 0.78 . Thus, the instrument was considered reliable and fit for use.

The pretest-TOEI was administered to the intact classes in the selected schools to establish the equivalence of the subjects for the study. Thereafter, the selected students were randomly sampled into the "experimental" and "control" groups. The normal school period for physics was used for the study. Three (3) periods per 
week of 40 minutes/period for two (2) weeks was used for the study. The constructivist Collaborative Learning Approach was used for the experimental group while the Demonstration approach was used for the control group. After the treatment for two weeks, the students were subjected to the same post-test-TOEI. The post test contains questions that test conceptual understanding of electromagnetic induction.

\section{RESULT}

\subsection{Pre-test Analysis for Control and Experimental groups}

The result in Table 1. shows that there is no significant difference in the Pretest mean scores of the control and experimental groups. This establishes the equivalence of both groups.

\subsection{Research Question 1}

What are the effects of Collaborative Learning Approaches on students' understanding of the concept of electromagnetic induction?

Result as shown in Table 2. shows an improvement in the mean performance of students taught with the Collaborative approach. The mean percentage of the pretest was 26.33 while that of the post test was 40.71. Also, the Table shows that the pretest scores are more homogenous with a standard deviation of 8.50 than those of the post test with a value of 9.68 .

\subsection{Research Question 2}

What are the effects of Demonstration Teaching Approach on students' understanding of the concept of electromagnetic induction?

The result as shown in Table 3 . shows a slight improvement in the understanding of students after being taught by Demonstration approach. The pretest mean percentage score was 26.82 while the post test score was 28.0. The pretest scores with standard deviation of 7.52 are more homogenous than the post test scores with standard deviation of 8.02 .

\subsection{Hypothesis}

There is no significant difference between the mean performance of students taught using Collaborative Learning Approach and those taught using Demonstration with respect to understanding of the concept of electromagnetic induction.

From Table 4, since the calculated t-value (9.55) is greater than the critical value (1.96) at $\alpha=$ 0.05 , the null hypothesis is rejected. This implies that there is a significant difference between the mean performance of students taught using Demonstration and Collaborative Learning Approaches with respect to understanding of the concept of electromagnetic induction and that students taught with Collaborative approach performed better than those taught by Demonstration approach.

Table 1. T- test comparison of pretest mean performances of experimental and control groups

\begin{tabular}{llllllll}
\hline Groups(pre tests) & Mean $(\bar{X})$ & SD & N & Df & $\mathbf{t}_{\text {cal }}$ & $\begin{array}{l}\mathbf{t}_{\text {crit, }} \\
\mathbf{a = 0 . 0 5}\end{array}$ & Significance \\
\hline $\begin{array}{l}\text { Collaborative } \\
\text { (Experimental) }\end{array}$ & 26.33 & 8.50 & 90 & 178 & -0.41 & 1.96 & Not significant \\
$\begin{array}{l}\text { Demonstration } \\
\text { (Control) }\end{array}$ & 26.82 & 7.52 & 90 & & & & \\
\hline
\end{tabular}

Table 2. Showing students' pretest and posttest scores when taught with collaborative approach

\begin{tabular}{lllll}
\hline & Pre-test & Post-test & Gain & Gain\% \\
\hline Mean $(\bar{X})$ & 26.33 & 40.71 & 14.38 & 54.61 \\
N & 90 & 90 & & \\
SD & 8.50 & 9.68 & & \\
\hline
\end{tabular}


Table 3. Showing students' pretest and post test scores when taught with demonstration approach

\begin{tabular}{lllll}
\hline & Pre-test & Post-test & Gain & Gain\% \\
\hline Mean $(\bar{X})$ & 26.82 & 28.00 & 1.18 & 4.47 \\
N & 90 & 90 & & \\
SD & 7.52 & 8.02 & & \\
\hline
\end{tabular}

Table 4. T-test comparison of post test mean performances of students taught using collaborative and those taught using demonstration approaches

\begin{tabular}{llllllll}
\hline Teaching Approach & $\operatorname{Mean}(\bar{X})$ & $\mathbf{S D}$ & $\mathbf{n}$ & $\mathbf{D f}$ & $\mathbf{t}_{\text {cal }}$ & $\mathbf{t}_{\text {crit, } \mathrm{a}=0.05}$ & Significance \\
\hline Collaborative & 40.71 & 9.68 & 90 & & & & \\
Demonstration & 28.00 & 8.02 & 90 & 178 & 9.55 & 1.96 & significant \\
\hline
\end{tabular}

\section{RESULTS AND DISCUSSION}

The result of the study showed that students taught using Collaborative Learning Approach obtained higher mean score than those taught using Demonstration approach. Testing Hypothesis 1 showed a significant difference in the mean performance of students taught with Collaborative approach and those taught with Demonstration approach Table 3. This may be attributed to the collaborative efforts of students learning together in groups. In collaborative classrooms, Students are encouraged develop critical thinking skills, they become active rather than passive learners thereby developing collaborative and co-operative skills which enable them to find solution to given tasks. According to [27], the benefits of collaborative group work amongst others include better understanding and retention of materials. The result justifies the observation of $[28,29,30,31]$ that students engaged in Collaborative learning capitalize on one another's resources and skills. This view is supported by [7], [32,33] that modern science teaching is focused on changing from teacher-centered approach to student centered approach which encourages students to take more interest in learning and that activity oriented methods avail students opportunity of peer tutoring. The fact that students are actively exchanging, debating and negotiating ideas within their groups increases students' interest in learning [34,35]. However, [36] differed in his opinion on the use of collaborative Learning for first year Legal Research, Writing and Analysis Course for legal students. He argued that such students are unlikely to gain sufficient working knowledge of the essential skills required for the Legal Research, Writing and Analysis Course and that such collaboration is likely to interfere with the progressive stages of the writing process. Successful collaborative learning is usually preceded by good planning - training the students to know what to do, grouping of the students, matching the given tasks with skills and abilities and assignment of roles to students, timing and the teacher acquainting himself with the use of the strategy.

\subsection{Implications of the Study}

One of the major findings of this research is that Collaborative Learning Approach was found to be more effective than Demonstration approach. The implication here is that teachers would need to develop themselves in the use of Collaborative Learning Approach in science classrooms. The approach requires that students have easy access to resources - books, libraries, science apparatus etc since the learners actively construct knowledge and are encouraged to explore their world, discover knowledge, reflect on and think critically. There is also the implication for learners to be aware of their responsibility in the learning process. The approach is learner-centered as students work in groups, mutually searching for understanding, solutions or meanings, or creating a product with the teacher as facilitator or guide.

The implication for government is that government will provide all learning resources laboratories, libraries and teachers to ensure the usability of the Collaborative approach in our secondary schools.

\section{CONCLUSION}

This research has shown that Collaborative Learning approach was found to be more effective than Demonstration approach in the area of study. The implication here is that 
teachers would need to develop themselves in the use of Collaborative Learning approach in science classrooms. The approach requires that students have easy access to resources - books, libraries, science apparatus etc since the learners actively construct knowledge and are encouraged to explore their world, discover knowledge, reflect on and think critically.

\section{RECOMMENDATION}

The following recommendations are made based on the findings of this study.

1. Based on the result that collaborative teaching strategy approach was found more effective, that Curriculum developers should incorporate constructivist strategies such as collaborative learning into the Physics curriculum by allocating more time to the teaching of physics since collaborative sessions take more time.

2. Government and other stake holders in the education industry should provide adequate resources as collaborative approach requires that students have easy access to resources - books, libraries and science apparatus since the learners actively construct knowledge and are encouraged to explore their world, discover knowledge, reflect on and think critically.

3. Science educators should incorporate collaborative and other modern constructivist instructional strategies into their teacher education program. This will ensure that trainee teachers are groomed in the effective use of the strategy.

\section{COMPETING INTERESTS}

Authors have declared that no competing interests exist.

\section{REFERENCES}

1. Breithaupt J. AQA Physics A. London: Nelson Thornes Limited; 2008.

2. Floyd TL, Buchla DM. Electric Circuits Fundamentals. $8^{\text {th }}$ edition, New Jersey: Pearson; 2010.

3. Perry J. The discovery of electromagnetic induction: world of mystery; 2010. Available:http://www.worldofmystery123.bl ogspot.com on 11/07/2011.

4. Ivowi UMO. Achievement level in understanding physics concepts in secondary schools. Journal of research in curriculum. 1983;1(2):23-34.

5. Akpan BB, (ed). Perspectives on Education and science teaching: from the eyes of Uduogie Ivowi. Ibadan: Foremost Educational Services; 1999.

6. Maduabum MA. Teaching integrated science effectively. Onitsha: space Matrix publications; 1989.

7. Dayal D. Modern Methods of teaching Physics. New Delhi: APH publishing; 2007.

8. SMASSE project. Physics training Manual for National inset. Kenya: Kenyan Literature Bureau; 2005.

9. Guisasola J, Almudi JM, Zuza K. University students' understanding of electromagnetic induction. International Journal of Science Education. 2013;35(16):2692 - 2717.

10. Galili I, Kaplan D, Lehavi Y. Teaching Faraday's law of electromagnetic induction in an introductory physics course. American Journal of Physics. 2006:74(4):337 - 343.

11. Windschitl $M$. The Challenges of Sustaining a Constructivist Classroom Culture. Phi Delta Kappan International; 1999.

12. Gbamanja SPT. Modern methods in science Education in Africa. Port Harcourt: paragraphics; 1999.

13. Alamina JI. Fundamental principles of science Teaching and learning. Port Harcourt: Votex Publishers; 2008.

14. Achuonye AK, Ajoku LT Foundations of curriculum Development and Implementation. Port Harcourt: Pearl Publishers; 2003.

15. Dillenbourg P. What do you mean by Collaborative learning? In P. Dilleribourg (Ed). Collaborative-learning: cognitive and computational Approaches. 1999;1-19. Oxford: Elsevier.

16. Mitnik $R$, Recabarren $M$, Nussbaum $M$, Soto A Collaborative robotic instruction: A graphic teaching experience. Computers \& Education. 2009;53(2):330-342.

17. Smith BL, Mac Gregor JT. What is Collaborative Learning? Collaborative Learning: A Source book for Higher Education. 1992;9-22. Available: http://edutechwiki.unige.ch/mediawiki/index php?

title $=$ collaboration and wikis8oldid $=25455$ on $01 / 02 / 2012$.

18. Federal Ministry of Education: National 
physics curriculum for senior secondary schools. Lagos: Federal Ministry of Education; 2009.

19. Adenike B. Identifying problems associated with study of physics in Lagos State, Nigeria; $2007 . \quad$ Available: www.wcpsd.org/boyo adenike1.pdf on 01/02/2012.

20. Epeya S. Relative effectiveness of constructivist instructional strategies on conceptual understanding of mechanical waves by senior secondary students in Okrika Local Government area. An unpublished PhD dissertation of the Rivers State University of Science and Technology; 2010.

21. Mkpanang JT. Effects of Computer Assisted Instruction (CAI) with drill and practice on Academic Achievement of students in physics. Nigerian Journal of Science and Science Education. 2010;8(2):72 - 86.

22. Hake RR. Interactive engagement versus traditional methods: A six-thousand student survey of mechanics test data for introductory physics courses. American Journal of physics. 1998;66:64-74.

23. Tiang $\mathrm{NH}$, Subramaniam $\mathrm{R}$. Teaching Electromagnetic induction through the use of Demonstration; 2008: Available: http:// www.fisica.uniud.it on 11/05/2011.

24. Peter OI, Abiodun AP, Jonathan OO. Effect of Constructivism instructional approach on teaching practical skills to mechanical related trade students in Western Nigeria Technical Colleges. International NGO Journal. 2010;5(3):059 - 064.

25. Onwioduokit FA. Science Education and Nation building: Curriculum implications.The Nigerian Journal of Curriculum and instruction. 2001;10(1):65 $-68$.

26. Yamane T. Statistics: An Introductory Analysis. $2^{\text {nd }}$ ed. New York: Harper and Row; 1967.

27. Davis BG. Cooperative Learning: Students Working in Small Groups. Speaking of
Teaching. 1999;10(2):1-4.

28. Guthrie IC, Wigfield A, Barbosa $P$, Perencevich KC, Taboada A, Davies $\mathrm{MH}$. Increasing reading comprehension and engagement through concept oriented teaching instruction. Journal of Educational psychology. 2004;56:403-423.

29. Kim B. The effects of a Constructivist Teaching Approach on Student Academic Achievement, self concept and learning strategies. Asia Pacific Education Review. 2005;6(1):7-19.

30. Kalender D. Applying the subject "cell" through Constructivist Approach during science lessons and the Teachers views. Journal of Environmental \& science Education. 2007;2(1):3-13.

31. Chui MM. Flowing toward correct contributions during groups' mathematics problem solving: A statistical discourse analysis. Journal of the learning sciences. 2008;17(3):415 - 463.

32. Baribor V. Learning Theories and Instructional processes. Owerri: Springfield publishers; 2003.

33. Adaramola MO, Onwioduokit FA. Relative effectiveness of Two problem - solving models on students' performance in Further Mathematics in Senior Secondary Schools in Rivers State. Nigerian Journal of Science and Science Education. 2010;8(2):24 - 45.

34. Dooly M. Constructing Knowledge Together. In Dooly, M. (ed.). Telecollaborative Language Learning: A guidebook to moderating intercultural collaboration online. Bern: Peter Lang; 2008.

35. Gillies R. The residual effect of cooperative learning experiences: A two year follow-up. Journal of Educational Research. 2004;96(1):15-20.

36. Elson JS. The Case Against Collaborative Learning in the First - Year Legal Research, Writing and Analysis Course. Perspectives: Teaching Legal Research and Writing. 2005;13(1):136 - 144.

(c) 2015 Adolphus et al.; This is an Open Access article distributed under the terms of the Creative Commons Attribution License (http://creativecommons.org/licenses/by/4.0), which permits unrestricted use, distribution, and reproduction in any medium, provided the original work is properly cited.

Peer-review history:

The peer review history for this paper can be accessed here: http://www. sciencedomain.org/review-history.php?iid=820\&id=21\&aid=7781 